\title{
Empirical models for estimating water retention curves in soil in Janaúba-MG, Brazil
}

\author{
Modelos empíricos de estimativa das curvas de retenção de água \\ no solo em Janaúba-MG, Brasil \\ Herlon B. Ferreira B. ${ }^{{ }^{*}}$, Rafael Oliveira B. ${ }^{1}$, Wesley de Oliveira $S .{ }^{1}$, Francisco G. Chaves $F^{1}{ }^{1}$, \\ Fabricia G. Bezerra C. ${ }^{1}$
}

\begin{abstract}
Retention curves describe water dynamics in the soil and represent the relationship between the energy of water retention and moisture content. Several empirical models of water retention curve settings in the soil are analyzed (Van Genuchten-VG, Brooks \& Corey BC, Bruce \& Luxmore-BL and Driessen-D). Deformed soil samples were collected at 10 sites per plot; a compound sample was established with 36 plots between October and November 2007, at depths 0-20 cm and 20-40 cm in the Irrigation District of Gorutuba in Janaúba MG, Brazil. Tensions used for tests were 10, 30, 100, 500 and $1500 \mathrm{kPa}$. Soil Water Retention Curve software was employed to obtain the parameters of the empirical equations. The performance of empirical models was obtained by the index suggested by Camargo \& Sentelhas, coupled to estimate standard error, standard deviation and coefficient of variation. The results showed that the VG model had the best performance compared to the other models tested for data on water retention in the soil. The BC model had the most unsatisfactory performance.
\end{abstract}

Key words: water use efficiency, performance, irrigation.

\section{RESUMO}

A curva de retenção é utilizada para descrever a dinâmica da água no solo, representando a relação entre a energia de retenção de água e o teor de umidade. O presente trabalho objetivou analisar vários modelos empíricos de ajuste das curvas de retenção de água no solo (Van Genuchten-VG, Brooks \& Corey-BC, Bruce \& Luxmore-BL e Driessen-D). Para tal, foram coletadas amostras deformadas de solo em 10 pontos por lote, compondo uma amostra composta, em 36 lotes de outubro a novembro de 2007, nas profundidades de 0 a $20 \mathrm{~cm}$ e 20 a $40 \mathrm{~cm}$, no Distrito de Irrigação do Perímetro Gorutuba, em Janaúba-MG. As tensões utilizadas nos ensaios foram: 10, 30, 100, 500 e $1500 \mathrm{kPa}$. Para obtenção dos parâmetros empíricos das equações utilizou-se o software Soil Water Retention Curve. O desempenho dos modelos empíricos foi obtido por meio do índice proposto por Camargo \& Sentelhas, erro padrão de estimativa, desvio padrão e coeficiente de variação. Os resultados indicaram que o modelo de VG apresentou o melhor desempenho em relação aos demais modelos testados para os dados de retenção de água no solo; e comparando os modelos estudados, o modelo BC apresentou desempenho não satisfatório.

Palavras-chave: uso eficiente da água, desempenho, irrigação.

\section{Introduction}

Soil capacity to store water and make it available for the growth and development of plants is directly related to several soil qualities, such as granulometry, mineralogy, aggregation status, distribution of pore size and others. The above qualities indicate the soil's capacity in retaining water and they are important to estimate the water retention curve in the soil (Tormena et al., 1998).
Water retention curve in the soil describes water dynamics in the soil (Van Genuchten, 1980; Dexter $\&$ Bird, 2001). The curve graphically represents the relationship between water retention energy (matrix potential on a logarithmic scale) and water content in the soil (soil moisture) which depends on the intrinsic characteristics of each type of soil. The latter is the result of a set of items such as texture, structure, mineralogy and organic matter (Beutler et al., 2002).

\footnotetext{
1 Universidade Federal Rural do Semi-Árido, Avenida Francisco Mota, n. 572, Presidente Costa e Silva, Campus Universitário, Mossoró RN Brazil, 59.625-900, Phone: (84) 3317-8301. E-mail: foboca@ hotmail.com

* Author for correspondence.
} 
Similar texture class soils may have retention curve of different aspects owing to the different types of granulometry in the same texture class, with different results in organic matter rates, clay type and soil structure constituting micro-aggregates.

Although knowledge on water retention in the soil is highly relevant to understand water infiltration, redistribution and availability for cultures (Walczak et al., 2006), its determination is time consuming and subject to hysteresis (Klute, 1986). Several researchers suggested mathematic and time saving models to estimate water retention curves.

Several models, such as those by Van Genuchten (1980), Brooks \& Corey (1964), Bruce \& Luxmore (1986) and Driessen (1986), have been suggested to adjust water retention curves in the soil, even though the former is the most employed.

Current research analyzes the performance of mathematical models to estimate the water retention curve in soil for samples collected on different lots in the Irrigation District of the Gorutuba Perimeter, Janaúba MG Brazil.

\section{Materials and Methods}

Constituting a compound sample per lot, simple deformed samples were collected in 36 lots between October and November 2007 at depths $0-20 \mathrm{~cm}$ and 20-40 cm, in the Irrigation District of the Gorutuba Perimeter, Janaúba MG Brazil. The region lies in the north of the state of Minas Gerais, $15^{\circ} 45^{\prime} \mathrm{S}$ and $43^{\circ} 15^{\prime} \mathrm{W}$, on the right bank of the river of the same name in the municipality of Nova Porteirinha MG Brazil. It extends itself throughout approximately 5,286 ha and is supplied from the Bico da Pedra reservoir by a $127-\mathrm{km}$ canal network, with a discharge of $6 \mathrm{~m}^{3} \mathrm{~s}^{-1}$.

According to the Survey in Irrigation and Pedological Mapping - Right Bank, undertaken by Codevasf (1978) within the irrigation project of the Gorutuba River basin, soils have been characterized by quartz sand, alluvial soil, loam soil, clayey soil, eutrophic and dystrophic latisol.

Soil samples were air-dried and sifted in a $2 \mathrm{~mm}$ sieve. They were then saturated in $1 \mathrm{~cm}-\mathrm{PVC}$ rings on previously saturated ceramic plates, submitted to a determined pressure until the maximum drainage of water in the pores according to tension applied. Sample's moisture was then calculated by weighing and drying in a buffer.
Tensions were 10, 30, 100, 500 and $1500 \mathrm{kPa}$. Soil Water Retention Curve Beta 3.0 was employed to obtain empirical parameters of equations and the models evaluated were Genuchten (1980) eq. 1, Brooks \& Corey (1964) eq. 2, Exponential (Bruce $\&$ Luxmore, 1986) eq. 3 and Driessen (1986) eq. 4.

$$
U_{g}=U_{\text {gres }}+\frac{U_{\text {gsat }}-U_{\text {gres }}}{\left[1+(\alpha h)^{n}\right]^{m}}
$$

Where $\alpha, n$ and $m$ are the equation's parameters, with $m=n-\frac{1}{n}$ (Mualem, 1976); $h$ is the water tension in the soil; $\mathrm{Ug}_{\mathrm{Sat}}$ and $\mathrm{Ug}_{\text {res }}$ are water contents respectively at saturation and at residual.

$$
U_{g}=U_{\text {gres }}+\frac{U_{g s a t}-U_{\text {gres }}}{(\alpha h)^{\lambda}}
$$

where $\alpha$ and $\lambda$ are the equation's parameters.

$$
U_{g}=-\frac{1}{\beta} \ln \left(\frac{h}{\alpha}\right)
$$

where $\alpha$ and $\beta$ are the equation's parameters.

$$
U_{g}=U_{g s a t} h^{-\gamma \cdot \ln (h)}
$$

where $\alpha$ and $\gamma$ are the equation's parameters.

Models' efficiency was evaluated by the following statistical parameters: performance index according to Camargo \& Sentelhas (1997), eq. 5; standard error of estimate, eq. 6; standard deviation, eq. 7; coefficient of variance, eq. 8.

Index of performance, $c$, shows the performance of a model or of a method with regard to standard rates. The following standards were used for comparison: tension rates versus moisture in laboratory and when compared to rates estimated by mathematical models.

$$
C=r . d
$$

in which $C$ is the index of performance; $r$ is the coefficient of correlation; $d$ is the coefficient of concordance, according to Willmott et al. (1985). 


$$
E P E=\sqrt{\frac{\sum_{i=1}^{n}\left(Y_{o b s}-Y_{e s t}\right)^{2}}{n}}
$$

in which $E P E$ is the estimate standard error; $Y_{o b s}$ is the rate observed, $Y_{\text {est }}$ is the rate estimated by the model; $n$ is the total number of pairs of observed and estimated rates.

$$
S=\sqrt{S^{2}}
$$

in which $S$ is the standard deviation and $S^{2}$ is the variance.

$$
C V=\frac{S}{\bar{X}} \cdot 100
$$

in which $C V$ is the coefficient of variance in percentage; $S$ is the standard deviation; $\bar{X}$ is the mean sample data.
Table 1. Criteria for a model's performance analysis by index $\mathrm{c}$.

\begin{tabular}{cl}
\hline Rate of performance index c & Performance \\
\hline$>0.85$ & best \\
0.76 a 0.85 & very good \\
0.66 a 0.75 & good \\
0.61 a 0.65 & fair \\
0.51 a 0.6 & bad \\
0.41 a 0.5 & very bad \\
$<0.4$ & worst \\
\hline
\end{tabular}

Source: Camargo \& Sentelhas (1997).

Table 1 shows criteria for the models' evaluation performance.

\section{Results and Discussion}

Table 2 shows mean, maximum and minimum

\begin{tabular}{|c|c|c|c|}
\hline Model & Statistics & Rate & Performance \\
\hline \multicolumn{4}{|c|}{ Depth $0-20 \mathrm{~cm}$} \\
\hline \multirow{3}{*}{ Van Genuchten (1980) } & Mean & 0.9793 & Best \\
\hline & Maximum & 0.9997 & Best \\
\hline & Minimu & 0.8833 & Best \\
\hline \multirow{3}{*}{ Brooks \& Corey (1964) } & Mean & 0.9045 & Best \\
\hline & Maximum & 0.9978 & Best \\
\hline & Minimum & 0.6551 & Good \\
\hline \multirow{3}{*}{ Bruce \& Luxmore (1986) } & Mean & 0.9213 & Best \\
\hline & Maximum & 0.9894 & Best \\
\hline & Minimum & 0.8336 & Very good \\
\hline \multirow{3}{*}{ Driessen (1986) } & Mean & 0.8925 & Best \\
\hline & Maximum & 0.9801 & Best \\
\hline & Minimum & 0.7676 & Very good \\
\hline \multicolumn{4}{|c|}{ Depth $20-40 \mathrm{~cm}$} \\
\hline \multirow{3}{*}{ Van Genuchten (1980) } & Mean & 0.9814 & Best \\
\hline & Maximum & 0.9993 & Best \\
\hline & Minimum & 0.9214 & Best \\
\hline \multirow{3}{*}{ Brooks \& Corey (1964) } & Mean & 0.8941 & Best \\
\hline & Maximum & 0.9981 & Best \\
\hline & Minimum & 0.6202 & Fair \\
\hline \multirow{3}{*}{ Bruce \& Luxmore (1986) } & Mean & 0.9123 & Best \\
\hline & Maximum & 0.9933 & Best \\
\hline & Minimum & 0.7905 & Very good \\
\hline \multirow{4}{*}{ Driessen (1986) } & Mean & 0.8925 & Best \\
\hline & Maximum & & Best \\
\hline & Minimum & 0.9801 & Very good \\
\hline & & 0.7676 & \\
\hline
\end{tabular}
rates of the performance index by the four evaluated

Table 2. Mean, maximum and minimum rates of performance index c for each model, at depths $0-20 \mathrm{~cm}$ and $20-40 \mathrm{~cm}$. 
Table 3. Rates of mean, standard deviation (SD) and coefficient of variance (CV) of moisture reported in the laboratory and estimated by models for each tension $\Psi(\mathrm{kPa})$.

\begin{tabular}{|c|c|c|c|c|c|c|c|c|c|c|c|c|c|c|c|}
\hline \multirow[t]{2}{*}{$\Psi(\mathrm{kPa})$} & Mean & SD & $\mathrm{CV}$ & Mean & SD & $\mathrm{CV}$ & Mean & SD & $\mathrm{CV}$ & Mean & SD & $\mathrm{CV}$ & Mean & SD & $\mathrm{CV}$ \\
\hline & \multicolumn{3}{|c|}{ Reported } & \multicolumn{3}{|c|}{$\begin{array}{c}\text { Van Genuchten } \\
\text { (1980) }\end{array}$} & \multicolumn{3}{|c|}{$\begin{array}{l}\text { Brooks \& Corey } \\
\text { (1964) }\end{array}$} & \multicolumn{3}{|c|}{$\begin{array}{l}\text { Bruce \& Luxmore } \\
\text { (1986) }\end{array}$} & \multicolumn{3}{|c|}{$\begin{array}{l}\text { Driessen } \\
(1986)\end{array}$} \\
\hline \multicolumn{16}{|c|}{ Depth $0-20 \mathrm{~cm}$} \\
\hline 10 & 0.24 & 0.06 & 0.25 & 0.24 & 0.06 & 0.25 & 0.29 & 0.10 & 0.35 & 0.22 & 0.06 & 0.28 & 0.21 & 0.05 & 0.25 \\
\hline 30 & 0.18 & 0.06 & 0.32 & 0.19 & 0.06 & 0.30 & 0.19 & 0.06 & 0.31 & 0.19 & 0.05 & 0.27 & 0.19 & 0.05 & 0.25 \\
\hline 100 & 0.14 & 0.05 & 0.34 & 0.14 & 0.05 & 0.33 & 0.14 & 0.04 & 0.31 & 0.16 & 0.04 & 0.28 & 0.16 & 0.04 & 0.26 \\
\hline 500 & 0.12 & 0.03 & 0.28 & 0.11 & 0.04 & 0.33 & 0.11 & 0.04 & 0.32 & 0.12 & 0.03 & 0.30 & 0.12 & 0.03 & 0.30 \\
\hline 1500 & 0.10 & 0.03 & 0.32 & 0.10 & 0.03 & 0.32 & 0.10 & 0.03 & 0.32 & 0.09 & 0.03 & 0.36 & 0.09 & 0.03 & 0.33 \\
\hline \multicolumn{16}{|c|}{ Depth $20-40 \mathrm{~cm}$} \\
\hline 10 & 0.23 & 0.06 & 0.26 & 0.23 & 0.06 & 0.26 & 0.28 & 0.09 & 0.33 & 0.21 & 0.06 & 0.29 & 0.21 & 0.05 & 0.26 \\
\hline 30 & 0.18 & 0.06 & 0.33 & 0.18 & 0.06 & 0.31 & 0.18 & 0.06 & 0.32 & 0.18 & 0.05 & 0.29 & 0.18 & 0.05 & 0.27 \\
\hline 100 & 0.14 & 0.05 & 0.37 & 0.14 & 0.05 & 0.36 & 0.13 & 0.05 & 0.34 & 0.15 & 0.05 & 0.30 & 0.16 & 0.05 & 0.29 \\
\hline 500 & 0.11 & 0.04 & 0.31 & 0.10 & 0.04 & 0.37 & 0.11 & 0.04 & 0.35 & 0.11 & 0.04 & 0.33 & 0.11 & 0.04 & 0.33 \\
\hline 1500 & 0.09 & 0.03 & 0.35 & 0.09 & 0.03 & 0.35 & 0.10 & 0.04 & 0.36 & 0.09 & 0.03 & 0.40 & 0.09 & 0.03 & 0.37 \\
\hline
\end{tabular}

models at the two depths under analysis. Performance of models varied from fair to best. Model according to Van Genuchten (1980) had the highest rate in the minimum, maximum and mean and its performance did not vary from the best.

Table 2 also shows that Brooks \& Corey's (1964) model had the lowest rates 0.65 and 0.62 respectively for depths $0-20 \mathrm{~cm}$ and $20-40 \mathrm{~cm}$. The lowest rates in performance index were found in the evaluated models.

Table 3 provides a statistical summary of moisture observed in the laboratory and estimated by the models under analysis. Low rates in standard deviation and coefficient of variance indicate low variability of mean rates of water in the soil when tension is investigated. Highest coefficient of variance rates (\%) were found at a depth between 20 and $40 \mathrm{~cm}$, whereas standard deviation rates decreased according to high tension rates albeit similar for the two depths. Table 3 also showed that lowest coefficient of variance rates were found for the Van Genuchten (1980) and Driessen (1986) models.

Table 4 provides rates of standard estimation error used for the evaluation of quality of the models under analysis to estimate moisture rates within the respective tensions investigated. Since the lowest rates of standard estimate error are attributed to the Van Genuchten model (1980), the model had the best moisture data adjustments with regard to tension. Rates also showed that the Brooks \& Corey's model (1964) had the highest rates of standard estimate error when compared to other models under analysis.
Table 4. Rates of standard estimate error for each model at two depths.

\begin{tabular}{lcc}
\hline Model & \multicolumn{2}{c}{ Standard estimate error } \\
\hline Depth & $0-20 \mathrm{~cm}$ & $20-40 \mathrm{~cm}$ \\
\hline Van Genuchten (1980) & 0.0049 & 0.0045 \\
Brooks \& Corey (1964) & 0.0247 & 0.0245 \\
Bruce \& Luxmore (1986) & 0.0117 & 0.0117 \\
Driessen (1986) & 0.0135 & 0.0134 \\
\hline
\end{tabular}

When the performance of the mathematical models was performed to estimate the water retention curve in the soil, it was verified (Table 3 ) that the Van Genuchten's model (1980) was that which most adjusted itself to data on water retention in the soil. It actually confirms its efficaciousness in forecasting water retention in the soil. Costa et al. (2008) also verified that Van Genuchten's model (1980) had the best adjustment when compared to Brooks \& Corey's model (1964).

\section{Conclusion}

Results show that within the context of statistical indexes used in the models' evaluation, Van Genuchten's model had the best performance when compared to that of the other models with regard to data on water retention in soil. On the other hand, the Brooks \& Corey's model showed an unsatisfactory performance when compared the models under analysis. 


\section{References Cited}

Beutler, A.N.; Centurion, J.F.; Souza, Z.M.; Andrioli, I.; Roque, C.G.

2002 Retenção de água em dois tipos de Latossolos sob diferentes usos. Rev. Bras. Ci. Solo, 26: 829-834.

Brooks, R.H.; Corey, C.T.

1964 Hydraulic properties of porous media. Fort Collins, Colorado State University. (Hydrology Paper, 3).

Bruce, R.R.; Luxmore, R.J.

1986 Water retention: field methods. In: Klute, A. (Ed.). Methods of soil analysis: Part 1 - Physical and Mineralogical Methods. Madison: ASA-SSSA, pp. 663-686.

Camargo, A.P.; Sentelhas, P.C.

1997 Avaliação do desempenho de diferentes métodos de estimativa da evapotranspiração potencial no Estado de São Paulo. Rev. Bra. Agrom., 5: 89-97.

\section{CODEVASF}

1978 Levantamento de aptidão para irrigação e mapeamento pedológico. Ministério da Integração Nacional - Companhia de Desenvolvimento do Vale do São Francisco.

Costa, W.A.; Oliveira, C.A.S.; Kato, E.

2008 Modelos de ajuste e métodos para a determinação da curva de retenção de água de um latossolo vermelho-amarelo. Rev. Bras. Ci. Solo, 32: 515-523.

Dexter, A.R.; Bird, N.R.A.

2001 Methods for predicting the optimum and the range of soil water contents for tillage based on the water retention curve. Soil Till. Res., 57: 203-212.
Dourado Neto, D.; Nielsen, D.R.; Hopmans, J.W.; Reichardt, K.; Bacchi, O.O.S.

2000 Software to model soil water retention curves (SWRC, version 2.00). Sci. Agr, 57: 191-192.

Driessen, P.M

1986 Land use system analysis. Wageningen.

Klute, A.; Dirksen, C.

1986 Hydraulic conductivity and diffusivity: laboratory methods. In: Klute, A. Methods of soil analysis. 2. ed. Madison: American Society of Agronomy, Soil Science Society of America, pp. 635-660.

Mualem, Y.

1976 A new model for predicting the hydraulic conductivity of unsaturated porous media. Water Res., 12: 513-522.

Tormena, C.A.; Silva, A.P.; Libardi, P.L.

1998 Caracterização do intervalo hídrico ótimo de um latossolo roxo sob plantio direto. Rev. Bras. Ci. Solo, 22: 573-581.

Van Genuchten, M.T.

1980 A closed-form equation for predicting the hydraulic conductivity of unsaturated soils. Soil Sci. Soc. of Ame. J., 44: 892-898.

Walczak, R.T.; Moreno, F.; Fernandez, E.; Arrue, J.L. 2006 Modeling of soil water retention curve using soil solid phase parameters. J. of Hydr., 329: 527-533.

Willmott, C.J.; Ackleson, S.G.; Davis, R.E. 1985 Statistics for the evaluation and comparison of models. J. of Geo. Res., 90: 8995-9005. 
